\title{
On the tones produced in a plate or a column by frequent discharges on an electrical machine
}

\section{E. Semmola}

To cite this article: E. Semmola (1885) On the tones produced in a plate or a column by frequent discharges on an electrical machine, Philosophical Magazine Series 5, 20:127, 548-548, DOI: $10.1080 / 14786448508627799$

To link to this article: http://dx.doi.org/10.1080/14786448508627799

曲 Published online: 29 Apr 2009.

Submit your article to this journal $\sqsubset$

Џ Article views: 2

Q View related articles ๘ 
If it be received on the screen, it appears as a bright spot on a feebly luminous ground, and changes after a lengthened action into a black spot, which has the same appearance as if a hale had been bored in a bright surface.

Instead of a solution of iodine or bisulphide of carbon, both which substances have their drawbacks, I use a solution of nigrosine in chloroform or alcohol. These solutions are quite black and only transmit ultra-red rays. Alcohol, it is true, strongly absorbs the ultra-red rays, so that the alcoholic solntion only gives a focus of small thermal action. This fact is, however, advantageous for the above experiment; for the luminosity of the very sensitive phosphoescent substance lasts longer, and the blackening does not set in so rapidly, as if the focus were more intense. The far more diathermanous solution in chloroform gives a sufficiently hot focus for demonstrating the thermal action; nigrosine is insoluble in the still more diathermanous bisulphide of carbon.

With the great sensitiveness of phosphorescent substances for ultra-red rays, the flame of gas, of a lamp, or even a candle is sufficient to show the phenomenon. By means of the spherical flask, or, still better, by means of a lens with interposition of a plane parallel trough filled with the black liquid, a sharp bright (positive) image of the flame is received on the screen; after the radiation has ceased this lasts with continually decreasing intensity, and then turns into a dark (negative) image on a brighter ground. This is a kind of photography by means of invisible ultra-red rays. Wiedemann's Annalen, No. 9, 1885.

ON THE TONES PRODUCED IN A PLATE OR A COLUMN BY FREQUENT

DISCHARGES OF AN ELECTRICAL MACHINE. BY E. SEMMOLA.

The conductors of an induction machine are connected, by means of two wires 5 metres in length, with two binding-screws fixed al the opposite sides of a brass plate 1 millim. in thickness, which rests on an ebonite funnel. If, now, the path of the current is broken so that sparks strike across, the brass plate begins to sound. It sounds also even if a Geissler's tube or a lead wire is interposed in the break; and also if instead, a wire is led to earth from the on binding-screw, and in this a break is made. If the end of the broken wire is so far removed from the binding-screw that sparks pass, the tone is stronger, and can be distinctly discriminated from the sound of the sparks.

Even if the wires are connected with a metal plate which stands opposite that on the hearing-apparatus, sounds are heard in the last-mentioned experiments. If the plate on the hearing-tube is connected with the earth, the note is stronger. The same is also slightly the case when a glass plate is interposed. If the wire leading to earth is not broken, no sound is heard.

If the wires are connected with the insulated wire of a sonorneter instead of with the brass plate, nothing is heard; if, however, an ebonite ear-trumpet is placed on the box the sound is audible.Beiblätter der Physik, vol. ix. p. 671. 